\title{
Political Opportunity, Mobilizing Structure, and Framing Process in Social Movement to Demand Special Autonomy in Yogyakarta 2010-2012
}

\author{
Andy Ilman Hakim, Meidi Kosandi \\ Graduate Program of Political Science Department \\ Universitas Indonesia \\ Depok, Indonesia \\ Email: andyilmanhakim@yahoo.com
}

\begin{abstract}
This research discusses the social movement to demand the appointment of the Sultan of Yogyakarta as the governor through the enactment of the law on Special Autonomy of Yogyakarta Province, without a free and fair election like in any other regions in Indonesia. The movement has its roots in history since the New Order, where there were protests and demonstrations among the public over the uniformity of local government system, including in the mode of election. After the reform of 1998, there were demands for Sultan HamengkuBuwono and PakuAlam to be enthroned as Governor and Vice Governor of Yogyakarta Province without anelection. The movement focused on the demands for the introduction of juridical rules governing the appointment of Sultan HamengkuBuwono and PakuAlam as Governor and Vice Governor of Yogyakarta.

This research uses the new social movement theory, explaining the three factors of the movement, i.e. political opportunity, mobilization structure, and framing process. It explains how political opportunities and mobilization structures are formed, and how social movement actors develop strategies and interact with their environment in building a common understanding in order to prepare society and engage in social movements. The research method used is a qualitative method with case study approach. The findings of the research indicate that the social movement in the case of Pro-Special Autonomy Yogyakarta movement is highly influenced by three factors. First, a political opportunity that creates opportunities for movement actors to take advantage of the momentum of the action. Second, the mobilization structure that represents the social structure of society. Third, the strategic framing process. These three factors strongly support the creation of social movements. The theoretical implications of this study illustrate partially anomalies in new social movement theories.
\end{abstract}

Keywords:social movement; pro-special autonomy; political opportunity; mobilization structure; framing process.

\section{INTRODUCTION}

After the end of the authoritarian regime, the growth of democracy as a new order in the life of society always followed by the growth of civil society. More broadly, the emergence of action groups also contributes to greater change, where its presence in a democratic country makes the position of civil society into a power of social and political struggle that is positively correlated to development[1]. In the study of social movements, civil society activism is often associated with a series of action group activities[2]. Some see the action group as an example of a global trend toward a new social movement, some see it as the ancestor of the transition to socialism, and others see as supporters of the emergence of civil society[3].
As an element of social movement, action groups tend to create collective movements through mobilization paths in the process of their struggle toward the goal of change. As many social movement studies show the various phenomena of social movements in America and Europe that emerged in the late 1960s and the range of 1970-1980. For example, the civil rights and anti-war struggle in America, "The Mai Revolt" in France in 1968, student protests in Germany, Britain, and Mexico, coalition of workers in the "Hot Autumn" action in Italy, women's movements and environment, and various other social movement phenomena[4].

In Indonesia, the study of social movements began to attract much attention after the reform era. At this momentum, community movements are encountered in various parts of Indonesia and bring up forms of tension and conflicts in the region. Like the mass 
riots that occurred in East Timor, Aceh, Papua, Riau, and Kalimantan, and other areas in Indonesia[5].

The most striking feature of some of these issues is the demands of different regions of political recognition and affirmation of their different identities. In addition to seeking a sense of justice, the demand for political recognition and affirmation is intended to secure special rights, including ensuring the survival of local wisdom values, and the development of their cultures freely and fully[6]. As seen in the phenomenon of the community movement that emerged in 1998 in Yogyakarta.

Social movement in Yogyakarta is a phenomenon of movement that occurred in the long term. The public struggle had been seen since 1998 until the achievement of demands in 2012. Various elements of society in Yogyakarta to do various forms of action in an attempt to maintain the privilege of Yogyakarta is reduced after the death of Sultan HamengkuBuwono IX. From the beginning, the people of Yogyakarta wanted the head of the province of Yogyakarta to be attached to the figure of Sultan HamengkuBuwono and PakuAlam who reigned. In the perspective of most of the people of Yogyakarta, there is no difference between the position of the Sultan and the Governor: the Sultan is the Governor and the Governor is the Emperor[7]. However, the existing juridical rules do not clearly govern the filling mechanism of the position.

In the next development, the demands of the centralized movement of the people so that the mechanism of filling the position of theregional head attached to the figure of Sultan HamengkuBuwono and PakuAlam who is entrenched in the rule of juridical strong and clear. The desire of the majority of the people of Yogyakarta is represented in several polls conducted by Kompas Research and Development. It is obvious that the majority of people of Yogyakarta want Sultan HamengkuBuwono who was entrusted, to be appointed Governor of Yogyakarta Province without going through the mechanism of elections.
TABLE I. The Polling Results OF Governor's Electoral MeChanism IN THE PROVINCE OF YOGYAKARTA

\begin{tabular}{|c|c|}
\hline Polling Time & $\begin{array}{c}\text { Result } \\
\end{array}$ \\
\hline 12 September 2008 & $\begin{array}{c}79.9 \% \text { of respondents choose } \\
\text { HamengkuBuwono X re-established } \\
\text { as Governor of Yogyakarta. }\end{array}$ \\
\hline 23-24 September 2008 & $\begin{array}{l}52.2 \% \text { of respondents agreed to the } \\
\text { determination of HamengkuBuwono } \\
\text { X as the Governor of Yogyakarta. }\end{array}$ \\
\hline 19 June 2009 & $\begin{array}{c}60.9 \% \text { of respondents chose } \\
\text { preferably the Governor of } \\
\text { Yogyakarta elected through the } \\
\text { determination. }\end{array}$ \\
\hline 22-23 December 2009 & $\begin{array}{c}65.7 \% \text { of respondents chose } \\
\text { HamengkuBuwono X set directly by } \\
\text { the government as the Governor of } \\
\text { Yogyakarta. }\end{array}$ \\
\hline 8 October 2010 & $\begin{array}{c}55.8 \% \text { of respondents chose } \\
\text { preferably the Governor of } \\
\text { Yogyakarta selected through the } \\
\text { determination. }\end{array}$ \\
\hline 22 October 2010 & $\begin{array}{l}53.5 \% \text { of respondents chose } \\
\text { preferably Governor of Yogyakarta } \\
\text { determined through determination. }\end{array}$ \\
\hline 1-3 December 2010 & $\begin{array}{l}\text { 88.6\% of respondents chose the } \\
\text { Governor of Yogyakarta directly } \\
\text { occupied Sultan. }\end{array}$ \\
\hline
\end{tabular}

The demands of the people of Yogyakarta who want the establishment of Sultan HamengkuBuwono $\mathrm{X}$ and PakuAlam IX as Governor and Vice Governor without going through the general election is directly interesting. Such demands are, of course, contrary to the spirit of democracy that should open the spaces of theleadership of the people, for the people, and by the people. Since the issue of privilege conical on the procedure of filling the office of Governor and Vice Governor, in fact, the attitude of society in Yogyakarta is not completely unanimous. There are many different views within the community itself. On the other hand, some community groups want direct elections, but on the other side, there are many people who want Sultan HamengkuBuwono X and PakuAlam IX to be automatically governed by Governor and Vice Governor[8].

In the course of post-reformation, the struggle of supportive society tends to subside and rise for a moment in certain moments. Especially at the momentum of the end of the YogyakartaGovernor's term. However, the community movement reemerged and strengthened in 2010 as a response to the President's statement regarding the monarchy system. 
Many times I have conveyed the basic position of the government in relation to the Law on Special Privileges of Yogyakarta or about the Government of the Special Territory of Yogyakarta. First of all the pillar is the national system, namely the Unitary State of the Republic of Indonesia which, in our Constitution, has been clearly regulated, including Article 18. And the second, it must also be fully understood privileges of the Special Territory of Yogyakarta itself from the historical expanse, other aspects that we should treat in particular, as set forth in our Constitution, must be visible within the governing structure of that privilege. But third, our country is a state of law and a real democracy. Therefore, the values of democracy, democratic value, should not be ignored because surely there can not be a monarchy system that collides with both the constitution and the values of democracy. I am sure that we can find a third institution that can be presented, the national system or the unity of NKRI, the second, the privileges we have to respect and uphold in Yogyakarta, and then the implicit implementation of democratic values for our country also contained in the 1945 Constitution.

Fig. 1. Kompas, 2011.

With regard to the statement, the Yogyakarta community's reaction in 2010 extended to public debate. The signals from the central government then stimulated the people of Yogyakarta to respond to the issue of Yogyakarta privileges in the form of protests. As happened in the community movement on December 13, 2010, in front of the Yogyakarta Provincial Parliament Building. In this context, the movement can also be interpreted as the Yogyakarta community movement as a form of rejection of the Yogyakarta draft regulation which was discussed by the government, which is contradictory and not in accordance with the aspirations of the people of Yogyakarta[9].

Based on the above issues, this study focuses on how political opportunities and mobilization structures are formed within the social movements of various elements of the Yogyakarta community so as to mobilize communities and collective action. As well as how social movement actors develop strategies and interact with their environment in shaping mutual understanding and creating social movements as an effort to maintain the privilege of Yogyakarta. This research uses a new social movement theory approach with thepolitical opportunity theory analysis unit, mobilization structure, and framing process in explaining the emergence of thesocial movement. The research method used is aqualitative method with case study approach. Data collection is done through observation, document collection, and in-depth interviews.

\section{THEORETICAL REVIEW}

\section{A. New Social Movement Perspective}

Conceptually, each expert has a different perspective in explaining the theory of social movements. From various perspectives, Diani concludes four main aspects in defining social movements, namely: a) networks of informal interactions; b) mutual trust and solidarity; c) collective action based on conflict-prone issues; d) actions taken outside of the institutional sphere as well as routine procedures in social life[10]. In general, Meyer describes a community of social movements should encompass various individuals and groups united by a common view within the region in which they are part of[11].

New Social Movement studies have based much of their study on issues of value transformation, culture, and identity, as well as social and political issues. Such as the peace movement, student movement, antinuclear protest movement, minority movement, homosexual rights movement, women's rights, animal rights, alternative medicine, religious fundamentalist movement, and environmental movement showing the expansion of issues within social movement phenomenon[12]. According to Touraine, the New Social Movement is a culturally engaged community movement within a social conflict, which seeks to control the cultural pattern (knowledge, investment, and ethics) that exists in a society, with obvious opponents, tends to reject the existing social order for creating change[13]. Meanwhile, according to Auda, as quoted by Haynes, said that new social movements always challenge the status quo - they are antisystem, calling for and integrating demands for changes in social, political, and economic order[14].

There are three important factors in analyzing social movements, namely political opportunities, mobilizing structures and framing processes. According to McAdam, to look at the dimensions of political opportunity, there are a number of indicators that can be used as analytical tools, such as: (1) the openness or the relative closeness of an institutionalized political system; (2) the stability of the political elite; (3) the availability of political elite associations; (4) the capacity of the state and the tendency of repression[15]. While the structure of mobilization (mobilizing structure), further highlight the existence of the organization as a container of social movement actors. A number of indicators that can be used include organizations from different 
walks of life, the formation of correlations and coordination among them in carrying out common functions. There are several important points in viewing the structure of mobilization in social movements, among which are tactical strategies, forms of social movement organizations, and the setting up of social movements [16].

Finally, the framing process relates to structuring and managing conditions to create a shared understanding on the basis of equal value. Zald outlines some important points in the framing process. First, it has cultural constructions of the repertoire of disagreements, the structure of the mobilized, and the framing. Second, there is thecontribution of the emergence of cultural contradictions and the flow of history in providing opportunities for framing. Third, the framing strategy generated by very diverse actors both from within and outside the movement, participates in the process of defining issues of concern, producing figurative terms, correlating errors, establishing tactics. Fourth, it has acompetitive process in determining to the frame, defining the situation, and dominating one another. Fifth, framing is disseminated and reframed in the mass media. Finally, it is understood that political opportunities and mobilization structures are interconnected with each other contributing to the form of framing competition[17].

\section{SOCIAL AND POLITICAL CONTEXT}

The roots of the emergence of Yogyakarta society movement cannot be separated from the historical facts of the birth of Yogyakarta Province and the social order of community life. The special status attached to the Yogyakarta Province contains a number of insights from several perspectives. As a province-level territory, Yogyakarta comes from the longstanding Sultanate of Ngayogyakarta Hadiningrat and Praja Paku Alaman. The position of the Sultanate of Ngayogyakarta Hadiningrat and Praja Paku Alaman is a sovereign territory long before Indonesia became independent. During this period, Yogyakarta has its own territory and people, and governance with the prevailing royal political system. The existence of the two kingdoms has inherited the concept of culture that fosters social life and shapes the cultural identity of the people of Yogyakarta. Philosophically, the order is formed is a unity of political entities that have a cultural identity in accordance with the philosophy of the establishment of the nation-state of Indonesia[18].

The joining of the two kingdoms into the territory of the Unitary State of theRepublic of
Indonesia is marked by the process of ijab kabul (political contract) between the leaders of Ngayogyakarta Hadiningrat Sultanate and Praja Paku Alaman with the President of the Republic of Indonesia. Ijab Kabul interpreted as a political contract that reinforces the position of Yogyakarta within the Republic of Indonesia is special. Mentioned on Sept. 5, 1945, special status contains the notion that all power in Yogyakarta is within the control of Sultan HamengkuBuwono and PakuAlam as regional heads who are directly responsible to the President. Then the presence of the 19 August 1945 State Charter affirmed the acceptance and acknowledgment of the state on the will of the contents of Sept. 5, 1945, Notes.

From the social perspective, the substance understanding of the specialty of Yogyakarta attached to the figure of Sultan HamengkuBuwono and PakuAlam who enthroned as Governor and Vice Governor. This is not apart from the original historical factor of the founding of Yogyakarta. According to Sukiman, the special status attached to Yogyakarta is inseparable from the contribution of Sultan Hamengku Buwono IX during Indonesian independence. The historical fact is considered as the main instrument why the substance of linear specialty with the figure of the Sultan[19]. Also according to Heru who saw three main aspects why Yogyakarta became special. First, the government history of Yogyakarta is closely related to the birth of the Republic of Indonesia. Second, the provincial and royal form of Yogyakarta which consists of the integratedKasultanan and Paku Alaman assets through the Political Contract consisting of the Charter of August 19, 1945, 5 September 1945, and October 30, 1945. Third, the Head of the Government ofYogyakarta consists of a dual-bundle leadership which is held automatically by Sultan HamengkuBuwono andPakuAlam who is entitled as a political right that has a direct relationship with the President of the Republic of Indonesia[20].

\section{FACTORS THAT IMPROVE THE MOVEMENT}

Compared to the 1998 movement, there are fundamental changes that occur in post-reform movements, especially the movement of 2010-2012. The emergence of Yogyakarta community elements across organizations and across professions that merged into the Pro-Special Autonomy Yogyakarta movement struggle of the privilege of Yogyakarta and the demand for the immediate enactment of juridical rules governing the privilege of Yogyakarta indicates that this movement is more politically and organized. 
According to David S. Meyer, such social movement communities have encompassed various individuals and groups united by a common view within the region in which they are part of [21].

The revival ofPro-Special AutonomyYogyakarta movement in 2010-2012, looks massive after the public atmosphere becomes unfavorable as President Susilo Bambang Yudhoyono's statement relates to the monarchy system that collided with the constitution and democratic values[22]. For Sukiman, Chairman of the Hamlet Association of Semar Sembogo Yogyakarta, the response shown by the central government in relation to the privilege of Yogyakarta is actually considered to revive community resistance and trigger widespread protests[23].

\section{B. Political Opportunity}

There are three main aspects that support the revival of the Pro-Special AutonomyYogyakartamovement of Yogyakarta's privileges. Firstly, the aspect of political opportunity which shows some important indicators is the opening of political access post-reformation of 1998, the formation of analliance of political elites that show the stability of support both at thelocal and national level, and state response which tends to accommodative and non-repressive. If observed, the openness of access in public space has opened the space for the actors of the movement to more freely fight for their interests directly facing the state actors, both legislative and executive. The opportunity can be seen from several audiences gradually with the Ministry of Home Affairs and Commission II of the House of Representatives. In addition, protest actions in the public sphere are also effective in influencing local stakeholders.

It can be shown from the description of ProSpecial AutonomyYogyakarta movement that coincides with the momentum of Yogyakarta Plenary Session of Parliament on December 13, 2010. The following points are the results of the decision of the Plenary Session of the Provincial Parliament of Yogyakarta on December 13, 2010: (1) Defend of Yogyakarta as a privileged area within the frame and system of government of the Unitary State of the Republic of Indonesia, (2) Filling the position of governor and vice governor of Yogyakarta Province through the mechanism of determination, (3) Sultan HamengkuBuwono and Sri PakuAlam who are enthroned as Governors and Vice Governors through the determination mechanism, (4) Urge the government and the House of Representatives to formulate and finalize the Special Privilege Bill of Yogyakarta based on the historical, philosophical, juridical and sociopolitical aspects of Yogyakarta[24].

According to McAdam, there are several common types of opportunities that indicate an increased likelihood of movement activity. First, there isdramatization of the striking difference between cultural values as a symbol and practice of conventional social life. Second, it has coercion of a sudden complaint. Third, there are dramatization as if the system became weak or the occurrence of invalidity in ways that are not in accordance with applicable law. Finally, innovative actors who are formed to be prepared as a figureto accommodate complaints and demands are emerged[25].

Departing from the perspective of McAdam, it can be identified that the increase of the Pro-Special AutonomyYogyakarta movement in 2010-2012 is a form of protest action against the striking difference between social system and cultural values that have long been practiced by the mechanism of filling the position of regional head apply in Indonesia. The continuous movement of activities by elements of society during the struggle period is also a form of coercion against the central government so that the demands of actors of the movement can be fulfilled.

From the perspective of political power, with regard to the attitude of political elites at both the regional and central levels, the data indicate the stability of support to the demands of society in 20102012. Withdrawn from the post-reformation period until the passage of the Special Law of Yogyakarta No.13 of 2012, there is at least a picture of the change in the attitude of the party factions at the local and national level regarding the pros and cons of Yogyakarta's privileges which indicate the direction of support to the demands of the Yogyakarta community movement[26].

Until 2010, changes in political attitudes of regional factions led to the support of political power for the privilege of Yogyakarta. The result of the decision of the Plenary Session of the Regional House of Representatives of theYogyakarta province is based on the number of votes for the number of seats of the faction consisting of votes supporting the Stipulation of the Governor and Vice Governor of Yogyakarta, among others, 11 PDIP votes, 8 PAN votes, 7 Golkar votes, 7 PKS votes, 5 Resurrection Factions Nation, 7 votes of Conscience Care of Indonesia Raya (Combined 4 political parties namely Gerindra, PPP, 
Hanura, PKPB). While the rest, as many as 10 votes from the Democratic Faction voted Disagree[27].

At the level of the central political elite, emerging responses show that the majority of political parties support the privilege of Yogyakarta. It is clear that at the end of 2010, the political power has depicted support for the privilege of Yogyakarta. The dominance and strength of the majority parties both at the local and national levels that support the privileges of Yogyakarta in 2010-2012 show the political strength in the political elite has been relatively stable[28].

In the context of social movements, the state's response contributes to the existence and activity of social movements. The state's response to the social movement determines whether therepressive action will strengthen or weaken movement activity. An important point of the state's response to the political upheaval that occurred in Yogyakarta was the government's non-repressive actions. One positive thing this indirectly provides flexibility for elements of the movement to conduct massive demonstrations or protests. Such as blood thumbprint stamps initiated by Hamlet community of Bantul Regency, mass action in the form of theatrical and symbolic when welcoming the president to Yogyakarta, even other actions in public space, including the Pro-Special AutonomyYogyakarta movement. Various forms of action involving large numbers of people, both large and partial, are occurring in areas where there is no repressive reaction from the government.

\section{Mobilizing Structure}

The process of the birth of social movements in the perspective of the mobilization structure is more focused on two main points, namely the existence of organizations as a forum for actors of movement, and the formation of correlation and coordination in carrying out joint functions. The emphasis on the political context can be seen from how social movement actors undertake demonstrative actions in the public sphere to achieve the desired goals. Usually, the activities undertaken relate to extraparliamentary movements. This movement seeks to suppress actors in the political sphere of both legislative and executive members, who are forced to make a policy based on the demands of society.

The elements of society involved in the struggle for the Pro-Special Autonomy Yogyakarta movementof the privileges of Yogyakarta can be identified as follows. First, there is Semar Sembogo community group from the lower level of society consisting of heads of the hamlet. Second, emerging organizations that formed based on a common interest in social movements such as the Gerakan Rakyat Yogyakarta, the Gentaraja, the Gerakan Rakyat Mataram, the Sekber Keistimewaan. And third, there are various communities such as art and cultural communities, lifestyle communities. Last but not least, professional associations such as community traders, pedicab drivers, and others.

TABLE II. SOCIAL MOVEMENTS ORGANIZATIONS

\begin{tabular}{|c|l|c|}
\hline No. & \multicolumn{1}{|c|}{ Group Name } & Identity \\
\hline 1 & Gerakan Semesta RakyatJogja (Gentaraja) & Civil society \\
\hline 2 & Gerakan Rakyat Mataram & Civil society \\
\hline 3 & Paguyuban Hamlet & Civil society \\
\hline 4 & Paguyuban Becak Pariwisata & Civil society \\
\hline 5 & Asosiasi Pedagang Pasar & Civil society \\
\hline 6 & Persatuan Warga Pendatang & Civil society \\
\hline 7 & Karang TarunaYogyakarta & Civil society \\
\hline 8 & Persatuan Wanita Yogyakarta & Civil society \\
\hline 9 & Persatuan Penarik Becak dan Andong & Civil society \\
\hline 10 & Persatuan Warga Bantul & Civil society \\
\hline 11 & Persatuan Warga Gunung Kidul & Civil society \\
\hline 12 & Persatuan Warga Kulon Progo & Civil society \\
\hline 13 & Pencinta Otomotif Yogyakarta & Civil society \\
\hline 14 & Majelis Silaturahmi Yogyakarta & Civil society \\
\hline 15 & Penggemar Sepeda Ontel Yogyakarta & Civil society \\
\hline 16 & Gerakan Rakyat Yogyakarta (GRY) & Civil society \\
\hline 17 & Koperasi Pasar “GemahRipah” & Civil society \\
\hline 18 & Sekber Keistimewaan & Civil society \\
\hline 19 & Persaudaraan Janda-Janda “Armalah” & Civil society \\
\hline 20 & Forum Intelektual Budayawan (Forinba) & Civil society \\
\hline & & Source: Aloysius Soni, Kompas, 2011 \\
\hline
\end{tabular}

In the context of the Pro-Special Autonomy Yogyakarta movement2010-2012, the elements of the social movement that actually formed also contained the old actors. The difference with the first people's session in 1998, the Pro-Special AutonomyYogyakarta movement of the year 20102012 tends to be more organized. The experience of ten years post-reformation gives its own advantages for the elements of the movement especially the actors of the movement. Partially, the first folk congress actors of 1998 transformed to develop their respective networks. In 1998 the movement's groups declared themselves as the Yogyakarta People's Movement. But in its development post-reform, grass-roots networks are formed and developed as the above data.

The movement's organization is a venue for movement actors to coordinate, unite their views, and accommodate the interests to create mutual understanding. The formation of correlations between movement organizations cannot be separated from the following points, such as the 
existence of provincial agendas that indirectly bring together other actors of the movement. For example, public hearing activities with Yogyakarta Parliament, central government representatives and members of the House of Representatives, as well as cultural rituals of pisowananageng, and even actions in the public sphere. From the meeting, there was a dialogue and gave birth to the parties who pioneered the importance of formulating and building the power to move together. The Pro-Special Autonomy movement specialties in 2010-2012, can not be separated from the process of forming a joint forum between elements of the movement to create a larger alliance.

The Pro-Special Autonomy Yogyakarta movement cannot be represented by a single organization that can claim the outcome of one organization's struggle. The mobilization structure formed is a process that involves the exchange of sustainable ideas, ideas, plans, and strategies to achieve mutually decided goals among the many actors and elements of the community involved. The ongoing negotiation process is even more important when the process of coordination and consolidation is taking place. Thus, the struggle for the privilege of Yogyakarta is embodied by a forum as a form of joint work. Where in it awaken a basis of interest and awareness of connectedness with each other [29].

McCarthy and Zald also see the importance of the organization's role in the social movement. According to him, the social movement contains what in it is called as a number of choices and beliefs that represent the desire of some elements in the social structure. The desire is then transformed into a movement through the mobilization of resources that require a strong political experience and good organizational judgment [31].Referring to the above opinion, the ability of the actors of the predetermination movement of Yogyakarta's privilege in managing and consolidating the action is also inseparable from the long experience of struggle that is able to form trust and represent shared desires.

There are two important aspects that are capable of supporting the activities of elements of the ProSpecial Autonomy Yogyakarta movement in creating joint solidarity. First is the relationship between patron and clients an important instrument to see the motivation of movement activity. Secondly, the traditions or cultures that serves as the connecting channel for the creation of shared functions. Judging from the activity of the movement elements in planning a number of action agendas, various forms of activities in the effort to mobilize strength can be seen as follows. Firstly, a number of meetings, coordination, and grassroots discussions that took place before the peak of the 2010 movement were a form of communication that was built by utilizing cultural channels. The utilization of cultural channels can be seen from the communication patterns built by movement actors in expanding the privilege issues down to the lower community level through the tradition of routine village-based meetings.

According to Sulistiyono, the communication developed between the actors of the movement with the lower level society, established since the emergence of the movement of Yogyakarta privileges as well as pisowananageng in 1998. Since then the public awareness to join in the struggle for the privilege of Yogyakarta has begun to take shape. Sulistiyono said public awareness can be seen when the public also has a desire to know the agenda of struggle privileges of Yogyakarta, including an understanding of the significance of why the privilege needs to be fought. Based on Sulistiyono's account, the society's understanding was initially limited to the knowledge that the substance of the specialty lies only in the Sultan's position as governor. In the end, however, frequent discussions have an impact on the knowledge of a more developed society in order to strengthen the privilege of struggle to be worth fighting for. At this point, the issue of predetermination of the privilege of Yogyakarta is formed as a common understanding [31].

The social ties that are reflected in the process of forming a common understanding among community members at the village level are in fact not only due to the intensity of encounters resulting from the utilization of cultural channels by movement actors. But it is also related to the pattern of social relations between the people and the Royal Palace that has long been formed due to the dependence on economic resources in the village area. Agricultural land is a potential land that supports the community economy at the village level. One of the main incomes of heads of hamlet comes from the agricultural land. According to Sukiman, Leader of the Hamlet Association of Semar Sembogo Yogyakarta, people at the village level depend on agricultural land (Sultan Ground) which is managed by the community as a source of the economy [32].

The palace policy gives villagers the freedom to manage agricultural land which is the land of Sultan 
Ground. Potential agricultural land at the village level provides income, especially for hamlet heads, as well as contributing to village life. The position of village heads at the village level places them as a respected figure and has a place in the community. This can not be separated from their central role in protecting and managing life in village and hamlet areas. Therefore it is fair when the issue of privilege and many people involved in the lowest level. Movement actors at the village level are able to reach out and utilize cultural channels to build solidarity, form a common understanding, to form a consolidation of hamlet levels.

The description of the economic system at the village level as described above has created a comfort zone for villagers, especially the heads of Hamlet, who indirectly cement their dependency relationship to the palace. In this context, the relationship of patron-client relations and movement activities is more visible in the process of remuneration, which is the result of relationships formed as a result of thedependence of elements of movement at the village level materially to the palace. According to Rauf, as a result of this, it causes clients to rely on sources of income to patrons [33].

For Sulistiyono, it is possible to invite people at the sub-village level to fight for the privilege of Yogyakarta. The organization's direct access can reach people at the sub-village level. According to him, support movements for the privilege of Yogyakarta from Bantul district, driven by the desire of the people.Even the financing and the need to hold discussion meetings, consolidation, and preparation of action derived from the kickback funds obtained from local community self-help. People's desire to maintain the privilege of Yogyakarta also came from other community groups [34]. For Suharsini, Head of the Gemah Ripah'sCooperative, his involvements, as well as members of the fruit merchants he leads in each of the actions supporting the privilege of Yogyakarta, are based on a number of reasons, such as a sense of security and serenity when Yogyakarta is led by a Sultan. According to him, the protection of the Yogyakarta palace and Pakualaman to the community, especially the fruit merchants he leads, is felt to provide security and avoid disturbances during trading activities [35].

Here are some reasons and motivations of movement actors obtained from the results of research interviews.
TABLE III. MOTIVATION OF Movement ACtors

\begin{tabular}{|c|c|c|}
\hline Informant & Organization & $\begin{array}{l}\text { Motivation } \\
\end{array}$ \\
\hline Sukiman & $\begin{array}{c}\text { Leader of Hamlet } \\
\text { Association Semar } \\
\text { Sembogo Yogyakarta }\end{array}$ & $\begin{array}{l}\text { Prosperity, History of } \\
\text { Yogyakarta, Dedication for } \\
\text { Sultan Hamengku Buwono IX, } \\
\text { Peaceful Situation. }\end{array}$ \\
\hline Sulistiyono & $\begin{array}{l}\text { Leader of Hamlet } \\
\text { Association Pandu } \\
\text { Bantul }\end{array}$ & $\begin{array}{l}\text { Prosperity, History of } \\
\text { Yogyakarta, Dedication for } \\
\text { Sultan Hamengku Buwono IX, } \\
\text { Peaceful Situation. }\end{array}$ \\
\hline Hasto & $\begin{array}{c}\text { Coordinator of } \\
\text { Sekber Keistimewaan }\end{array}$ & \begin{tabular}{lrr} 
History of & \multicolumn{2}{c}{ Yogyakarta, } \\
Dedication & for & Sultan \\
Hamengku & Buwono & IX, \\
Culture Preservation. & \\
\end{tabular} \\
\hline Gazali & $\begin{array}{l}\text { Leader of Gerakan } \\
\text { Rakyat Yogyakarta }\end{array}$ & $\begin{array}{l}\text { History of Yogyakarta, } \\
\text { Yogyakarta Contribution for } \\
\text { Indonesia, Dedication for } \\
\text { Sultan Hamengku Buwono IX. }\end{array}$ \\
\hline $\begin{array}{c}\text { Heru } \\
\text { Wahyukismoyo }\end{array}$ & $\begin{array}{l}\text { Academician, } \\
\text { Former of } \\
\text { Yogyakarta } \\
\text { Parliamentarian }\end{array}$ & $\begin{array}{l}\text { Yogyakarta Contribution for } \\
\text { Indonesia, Culture } \\
\text { Preservation, Dedication for } \\
\text { Sultan Hamengku Buwono IX. }\end{array}$ \\
\hline Suharsini & $\begin{array}{l}\text { Leader of Gemah } \\
\text { Ripah Cooperative }\end{array}$ & $\begin{array}{l}\text { Peaceful Situation, Dedication } \\
\text { for Sultan Hamengku Buwono } \\
\text { IX. }\end{array}$ \\
\hline
\end{tabular}

The mobilization factor ultimately tends to focus on culture and symbolic issues relating to a sense of membership sentiment in the different social groups whose members feel powerful. The elements of Yogyakarta society describe such sentiments as a form of action against the dominance of the state. They are like having a subculture orientation that challenges the dominant system. In this context, the new social movement sees this as a form of preserving identity [36].

\section{Framing Process}

The process of framing in the context of the struggle for the Pro-Special Autonomy Yogyakarta movement in 2010-2012 relates to the process of arranging and managing conditions to create an integration of the movement. The unification of perceptions of issues relating to privileges will create a shared understanding on the basis of common values and goals. Various forms of movement activities conducted by the actors of the Pro-Special Autonomy Yogyakartamovement are seen as an effort to create conditions that bring psychological impacts both for the actors of the movement itself, as well as to the people of Yogyakarta widely. It starts from how motion actors define the root of the problem, identifies the opponent, and determine the right predictions and strategies. This effort is made to develop common perceptions that can be used as motivation to create a common movement to achieve the goals of the social movement. 
The Pro-Special Autonomy Yogyakarta movement focuses on the substance of the privilege of the filling mechanism. The struggle to defend Sultan HamengkuBuwono and PakuAlam who entrusted to be automatically designated as Governor and Vice Governor of Yogyakarta Province has become a frame with the movement of elements of Pro-Special Autonomy Yogyakarta specialty since postreformation. Consistency on issues of privilege related to the mechanism of filling the office of Governor and Vice Governor is intended to revive the substance of the privilege in Yogyakarta.

Since the New Order period until the second passing of the Law of Privilege of Yogyakarta in 2012, there are some things that disturb the community related to the privilege of Yogyakarta. First, not immediately inaugurated Sultan Hamengku Buwono $\mathrm{X}$ as Governor after Sultan HamengkuBuwono IX died. Secondly, not immediately the formulation of juridical rules that legally shelter the privilege of Yogyakarta, especially regarding the mechanism of filling the position of Governor and Vice Governor of Yogyakarta Province. Third, the inhibition of community aspirations accompanied by the slow pace of political will from government or policymakers to immediately accommodate the will of the community [37]. The reason is the capital for the actors of the movement to frame the situation as if the central government did not support the aspirations of the people of Yogyakarta.

Actors of the social movement element of the privilege of Yogyakarta are aware of the strength of the state structure when compared to the mass forces. So there are two currents of movement surrounding the journey of privilege, namely joint mass movements as extra-parliamentary movements, as well as efforts of lobbying and advocacy to deal directly with policymakers. These two paths are taken because it is not easy for the pre-determination movement of the privilege of Yogyakarta if only prioritizing mass mobilization. They realize that building relationships with political elites can effectively open up opportunities for their accommodation.

The use of the movement's merging strategy can be translated as an effort to mobilize forces and facilitate the flow of movement coordination to achieve mutual understanding. It can also be said to be an attempt to establish a collective identity. According to Melucci, collective identity is an interaction and formation of shared understandings that are produced from several individuals (or groups at a more complex level), whose focus is action-oriented, particularly with regard to the opportunities and coercion in which the action takes place [38]. The framing process then gains political leverage and becomes one of the forces to urge policymakers when privileged issues become publicity material for the media. Awareness of the importance of the role of the media, bringing some elements of the movement focused on building opinions using relationships with news reporters.

TABLE IV. STRATEgy ANd Assignment of Movement ACtors

\begin{tabular}{|c|c|c|}
\hline Informant & Organization & Focus of Assignment \\
\hline Sukiman & $\begin{array}{c}\text { Leader of Hamlet } \\
\text { Association Semar } \\
\text { Sembogo } \\
\text { Yogyakarta }\end{array}$ & $\begin{array}{l}\text { Mass Mobilization, Discussion } \\
\text { with the community, Opinion } \\
\text { building, Advocacy, Building } \\
\text { relationships with thepolitical } \\
\text { elite. }\end{array}$ \\
\hline Sulistiyono & $\begin{array}{l}\text { Leader of Hamlet } \\
\text { Association Pandu } \\
\text { Bantul }\end{array}$ & $\begin{array}{l}\text { Mass Mobilization, Discussion } \\
\text { with the community, Opinion } \\
\text { building, Advocacy, Building } \\
\text { relationships with local elite. }\end{array}$ \\
\hline Hasto & $\begin{array}{l}\text { Coordinator of } \\
\text { Sekber } \\
\text { Keistimewaan }\end{array}$ & $\begin{array}{l}\text { Network setup and Opinion } \\
\text { building, }\end{array}$ \\
\hline Gazali & $\begin{array}{l}\text { Leader of Gerakan } \\
\text { Rakyat Yogyakarta }\end{array}$ & $\begin{array}{l}\text { Mass Mobilization and } \\
\text { Network setup. }\end{array}$ \\
\hline $\begin{array}{c}\text { Heru } \\
\text { Wahyukismoyo }\end{array}$ & $\begin{array}{l}\text { Academician, } \\
\text { Former of } \\
\text { Yogyakarta } \\
\text { Parliamentarian }\end{array}$ & $\begin{array}{l}\text { Opinion building and Building } \\
\text { relationships with thepolitical } \\
\text { elite. }\end{array}$ \\
\hline Suharsini & $\begin{array}{l}\text { Leader of Gemah } \\
\text { Ripah Cooperative }\end{array}$ & $\begin{array}{lll}\text { Mass Mobilization } & \text { and } \\
\text { Discussion } & \text { with } \\
\text { community. } & & \end{array}$ \\
\hline
\end{tabular}

According to Zald, the process of framing is not limited to the existence of cultural constructs built as a result of cultural contradictions and contradictions. However, activities for movement can occur through strategies generated by motion actors in the framing process, whether related to the process of defining the issue, producing figurative terms, linking errors and establishing tactics. Where the results of the framing process can be disseminated and reframed by the mass media [39].In the context of the Yogyakarta Pro-determination Movement, the effort to integrate the movement through theintensity of joint forum meetings, public discussions, network arrangement, opinion building, and media publications is part of the strategy in the framing process. In terms of process, these strategies are a strategic activity in the process of social movement. 


\section{CONCLUSION}

The efforts to reduce the privilege of Yogyakarta during the New Order regime era initially did not cause significant protests. Until then came the political reform momentum of 1998, which marked the opening of political access followed by reform movement in Yogyakarta. The community movements are then integrated with the demand that Sultan HamengkuBuwono and PakuAlam who enthroned immediately be sworn in as Governor and Vice Governor of Yogyakarta Province automatically. In its development, the movement was followed by the demand for the establishment of juridical rules that can regulate the privileges of Yogyakarta. This is based on historical facts that explain how special status is attached to Yogyakarta.

This research seeks to explain how political opportunities and mobilization structures are formed in social movements. It also includes how social movement actors develop strategies and interact with their environment in shaping mutual understanding and creating social movements. The result of this research concludes that social movement in the case of Pro-Special Autonomy Yogyakarta movement in Yogyakarta is very influenced by three factors. First, a political opportunity that creates opportunities for movement actors to take advantage of the momentum of theaction. And second, the mobilization structure that represents the social structure of society. As well as a strategic framing process. These three factors strongly support the creation of social movements.

ThePro-Special AutonomyYogyakartamovement research of the privileges of Yogyakarta partially indicates the anomaly of new social movement theories. First, the phenomenon of thePro-Special AutonomyYogyakartamovement complements an argument that the purpose of a new social movement by movement actors in fighting for a demand is not always described as a form of effort to fight for change within the society. Efforts to maintain the old system are also a consideration when the longestablished social order is considered more capable of offering the fulfillment of needs for society. Secondly, the struggle to establish Sri Sultan HamengkuBuwono and PakuAlam as governor and deputy governor show the attempt to maintain the status quo that indirectly describes the process of abolishing or giving up the political rights of individuals in society to the king.

\section{REFERENCES}

[1] G. White, Civil Society, "Democratization and Development: Clearing the Analytical Ground", in P. Burnell dan, P. Calvert, "Civil Society in Democratization". London: Frank Cass and Company Limited, 2004, pp.7-19.

[2] J. Haynes, "Demokrasi \& Masyarakat Sipil di Dunia Ketiga: Gerakan Politik Baru Kaum Terpinggir". Jakarta: Yayasan Obor Indonesia, 2000, pp.7-9.

[3] Ibid, pp.23.

[4] D.D. Porta andM. Diani, Social Movements: An Introduction $2^{\text {nd }}$ ed. Oxford UK: Blackwell Publishing, 2006, pp.1.

[5] Stokhof and M. Djamal, Konflik Komunal di Indonesia Saat Ini. Jakarta: INIS, 2003, pp. 15-75.

[6] N. Soeseno, Kewarganegaraan: Tafsir, Tradisi dan Isu Kontemporer. Jakarta: Universitas Indonesia, 2010, pp.80-91.

[7] Cornelis Lay, Keistimewaan Yogyakarta: Naskah Akademik dan Rancangan Undang-Undang Keistimewaan Yogyakarta. Yogyakarta: PLOD Fisipol UGM, 2008, Monograph on Politics \& Government, Vol.1, No.2, pp.21-22.

[8] A. Darmawan, Peran Ruang Publik dalam Mendukung Keistimewaan DIY. Depok: Universitas Indonesia, 2009, pp. 189-191

[9] J.A. Pasha, Salah Paham Soal Yogyakarta, inA. Soni, Monarki Yogya: Inkonstitusional?,Jakarta: Kompas, 2011, pp. 214-215.

[10] M. Diani, The Concept of Social Movement, The Sociological Review, 1992, pp.7-13.

[11] D. S. Meyer, Opportunities and Identities: BridgeBuilding in the Study of Social Movements. pp.12, in D. S. Meyer, N. Whittier, dan B. Robnett (ed.), Social Movements: Identity, Culture, and The State. Oxford University Press, Inc, 2002.

[12] E. Larana, H. Johnston, and J. R. Gusfield (ed), New Social Movements: From Ideologi to Identity. Philadelphia: Temple University Press, 1994.pp.3.

[13] A.Touraine, An Introduction to the Study of Social Movements, Social Research, Vol.52, No.4, (WINTER 1985), pp.772-777.

[14] J. Haynes, Demokrasi \& Masyarakat Sipil di Dunia Ketiga: Gerakan Politik Baru Kaum Terpinggir. Jakarta: Yayasan Obor Indonesia, 2000, pp.1.24.

[15] McAdam, McCharty, and Zald (eds), Comparative Perspectives on Social Movements. Cambridge University Press, 1996, pp.27.

[16] McCharty, "Constraints and Opportunity in Adopting, Adapting, and Inventing," in McAdam, McCharty, and Zald (eds), Comparative Perspectives on Social Movements. Cambridge University Press, 1996, pp.141-144.

[17] M. N. Zald, "Culture, Ideology, and Strategic Framing", in McAdam, McCharty, and Zald (eds), Comparative Perspectives on Social Movements. Cambridge University Press, 1996.pp.261-274.

[18] H. Wahyukismoyo, Merajut Kembali Pemikiran Sri Sultan Hamengku Buwono IX. Yogyakarta: Dharmakaryadhika, 2008. pp.3-8.

[19] Interview with Sukiman, Leader of Hamlet Association Semar Sembogo Yogyakarta, 29 April 2017.

[20] H. Wahyukismoyo, Merajut Kembali Pemikiran Sri Sultan Hamengku Buwono IX. Yogyakarta: Dharmakaryadhika, 2008, pp.178-179. 
[21] D. S. Meyer, "Opportunities and Identities: BridgeBuilding in the Study of Social Movements", pp.12, in D.S. Meyer, N. Whittier, andB. Robnett (ed.), "Social Movements: Identity, Culture, and The State". Oxford University Press, Inc, 2002.

[22] J.A. Pasha, "Salah Paham Soal Yogyakarta", in Aloysius "Moni, "Monarki Yogya: Inkonstitusional?". Jakarta: Kompas, 2011, pp. 213.

[23] Interview with Sukiman, Leader of Hamlet Association Semar Sembogo Yogyakarta, 29 April 2017.

[24] W. Nugroho, in Aloysius Soni, "Monarki Yogya: Inkonstitusional?", Jakarta: Kompas, 2011, pp. 223.

[25] D. McAdam, "Conceptual Origins, Current Problems, Future Directions", in McAdam, McCharty, and Zald (eds), "Comparative Perspectives on Social Movements". Cambridge University Press, 1996, pp.25.

[26] A. Darmawan," Peran Ruang Publik dalam Mendukung Keistimewaan DIY. Depok: Universitas Indonesia, 2009, and Kompas Newspaper edition 14 November 2010.

[27] Kompas Newspaper edition 14 November 2010, "Yogyakarta Tentukan Sikap."

[28] Kompas Newspaper edition 11 Desember 2010, "Setgab Terpecah Soal Jogja".

[29] D. Triwibowo, Gerakan Sosial: Wahana Civil Society bagi Demokratisasi. Jakarta: LP3ES, 2006, pp.6.

[30] M. Diani, The Concept of Social Movement, (The Sociological Review, 1992), pp.4.
[31] Interview with Sulistiyono, Leader of Hamlet Association Pandu Bantul, 29 April 2017.

[32] Interview with Sukiman, Leader of Hamlet Association Semar Sembogo Yogyakarta, 29 April 2017.

[33] M. Rauf, Konsensus dan Konflik Politik. Jakarta: Direktorat Jenderal Pendidikan Tinggi Depdiknas, 2001, pp. 102.

[34] Interview with Sulistiyono, Leader of Hamlet Association Pandu Bantul, 29 April 2017.

[35] Interview withSuharsini, Leader of Gemah Ripah Cooperative, tanggal 3 Mei 2017.

[36] E. Larana, Hank Johnston, dan Joseph R. Gusfield (ed), New Social Movements: From Ideologi to Identity. Philadelphia: Temple University Press, 1994, pp.10.

[37] Cornelis Lay, Keistimewaan Yogyakarta: Naskah Akademik dan Rancangan Undang-Undang Keistimewaan Yogyakarta, (Yogyakarta: PLOD Fisipol UGM, 2008), Monograph on Politics \& Government, Vol.1, No.2.

[38] E. Larana, Hank Johnston, dan Joseph R. Gusfield (ed), New Social Movements: From Ideologi to Identity. Philadelphia: Temple University Press, 1994, pp.15.

[39] Mayer N. Zald, "Culture, Ideology, and Strategic Framing", in McAdam, McCharty, and Zald (eds) "Comparative Perspectives on Social Movements". Cambridge University Press, 1996, pp.261-274. 